\title{
Toxicity assessment of an effluent derived from an inactivated uranium mine: the Poços de Caldas (Brazil) example
}

\author{
M.C. Artal ${ }^{\text {A,* }}$, G. De-Almeida ${ }^{\text {A }}$, A.Caloto-Oliveira ${ }^{\text {A }}$, M.A.P.F. Santos ${ }^{\text {A }}$, G.A. Umbuzeiro ${ }^{\text {A }}$ \\ \& C.M.R. CONEGLian ${ }^{A}$
}

A UNICAMP, Faculdade de Tecnologia, Universidade de Campinas, Laboratório de Ecotoxicologia e Microbiologia Ambiental "Prof. Dr. Abílio Lopes”, R. Paschoal Marmo, 1888, 13484-332. Limeira, SP, Brazil.

(Received September 29, 2011; Accept February 12, 2012)

\begin{abstract}
Uranium mines can cause environmental impact because of acid mine drainages can reaches the surrounding water bodies. In this work we tested effluent samples from an inactivated uranium mine located in Poços de Caldas city (Minas Gerais, Brazil) for acute and chronic toxicity. Untreated effluents were acutely toxic to Daphnia similis, with $\mathrm{EC}_{50}(48 \mathrm{~h})$ varying from $<0.01 \%$ to $38 \%$. Both treated and untreated effluent samples presented chronic toxicity to Ceriodaphnia dubia. Vibrio fischeri acute toxicity tests were negative for all tested samples. Adjustment of $\mathrm{pH}$ performed in samples was not sufficient to remove acute toxicity indicating that not only $\mathrm{pH}$ was responsible for the observed effect. The physical-chemical treatment applied was not able to remove the chronic toxicity to C. dubia. V. fischeri, although a rapid test and easy to handle, was not sensitive to the level of toxicants present in the effluent from the mine. To determine the actual impact of the discharge of effluent into receiving waters, both the flow of the effluent and river should be considered. Nevertheless chronic toxicity tests with C. dubia could be included in the monitoring program of this facility to provide more information about the impact of this discharge.
\end{abstract}

Key-words: Acid mine drainage, Ceriodaphnia dubia, Daphnia similis, ecotoxicity, Vibrio fischeri.

Avaliação da toxicidade do efluente proveniente de uma mina de urânio inativada em Poços de Caldas (Brasil)

\section{Resumo}

Efluentes provenientes de minas de urânio podem impactar corpos de água adjacentes devido às drenagens ácidas de mina. Neste trabalho, foram testadas amostras de efluentes de uma mina de urânio inativada, localizada na cidade de Poços de Caldas (Minas Gerais, Brasil) para a toxicidade aguda e crônica. Efluentes não tratados foram tóxicos para Daphnia similis, com $\mathrm{CE}_{50}$ (48 h) variando de $<0,01 \%$ a $38 \%$. Ambas as amostras de efluentes, tratadas e não tratadas, apresentaram toxicidade crônica para Ceriodaphnia dubia. Testes de toxicidade realizados com Vibrio fischeri foram negativos para todas as amostras testadas. $\mathrm{O}$ ajuste de $\mathrm{pH}$, realizado em algumas amostras, não foi suficiente para remover a toxicidade aguda, indicando que somente o pH não foi responsável pelo efeito observado. O tratamento físico-químico aplicado nesses efluentes dentro da mina, não foi capaz de remover a toxicidade crônica para C. dubia. O teste de toxicidade com $V$. fischeri, embora seja um teste rápido e fácil de manusear, não foi sensível para as amostras empregadas. Para determinar o real impacto da descarga desses efluentes, oriundos da drenagem ácida de mina, em águas receptoras, as vazões do efluente e do rio devem ser consideradas. O teste de toxicidade crônica com C. dubia poderia ser incluído no programa de monitoramento da mina para fornecer mais informações sobre o impacto dessa descarga.

Palavras-chave: Drenagem ácida de mina, Ceriodaphnia dubia, Daphnia similis, ecotoxicidade, Vibrio fischeri.

*Corresponding author: Mariana Coletty Artal; e-mail: mariartal@gmail.com 


\section{INTRODUCTION}

Inactivated and abandoned uranium mines are a significant challenge to manage and a potential risk to environmental and human health. The main impacts of a uranium mine are usually related to its high volume of tailings and acid mine drainages (AMD). AMD are caused by oxidation of natural metallic sulfites in the presence of water and oxygen, resulting in sulfuric acid and several dissociated metals. AMD is a complex mixture of several metals and radioactive species, usually with low $\mathrm{pH}$ and significant radioactivity (Fernandes et al., 1998; Wiikman, 1998; Cipriani, 2002). Production of AMD is a high concern, because of the difficulties of its treatment and remediation (Galán et al., 2003; Lin et al., 2007; Antunes et al., 2008). These waters are rich in hazardous chemicals and radioactive elements that can also be transferred to different environmental compartments, such as soil and plants (Neves et al., 2008).

In the literature there are some studies demonstrating the toxicity of uranium mine effluents and their environmental impacts (Antunes et al., 2007a, b). Some authors studied the toxicity of uranium and derived ecotoxicity threshold values to a several terrestrial and aquatic organisms. Uranium is a naturally occurring radioactive element that decays to other elements, such as radon, lead, polonium and bismuth, which are equally toxic to most living organisms (Vera Tome et al., 2002; Sheppard et al., 2005).

In Brazil, the management of the inactivated uranium mine plant of Poços de Caldas is a new and a challenging reality for both environmental and nuclear agencies. It was one of the first uranium mines explored in Brazilian territory. The management consists of a two- phase physical-chemical treatment: first the precipitation of metals using $\mathrm{CaO}$ and $\mathrm{CaCO}_{3}$ and second the use of $\mathrm{BaCl}_{2}$. The final effluents are discharged into receiving water bodies in the surroundings of the mine.

Current Brazilian water legislation does not address specific uranium criteria for the discharge of effluents in water bodies (CONAMA, 2005, 2011). The discharge of uranium mine effluents are mostly assessed by: $\mathrm{pH}$, dissolved metals (Mn, Fe, F, and $\mathrm{Al}$ ), and both acute and chronic toxicity to aquatic organisms (CONAMA, 2005; Rubio and Silva, 2010). To our knowledge, there is no routine toxicity monitoring of the discharged effluents from this inactivated uranium mine, in order to avoid negative impacts over native organisms, nor any concern about the dilution rates of mine effluent into receiving water bodies.

In the present study, we used three bioassays to assess the toxicity of acid mine drainages samples before and after physical-chemical treatment: acute assays with Daphnia similis and Vibrio fischeri, and the chronic assay with Ceriodaphnia dubia. Both cladocerans are key species in freshwater food chains and standardized test-organisms. The $V$. fischeri assay was also included because of its simplicity and potential on field monitoring programs, which could allow for rapid and easy-to-handle assessments.

\section{MATERIAL AND METHODS}

\section{Site characterization and sampling}

The studied inactivated uranium mine is located at Poços de Caldas city, Minas Gerais state, Brazil (21 $\left.{ }^{\circ} 45^{\prime} \mathrm{S}, 46^{\circ} 35^{\prime} \mathrm{W}\right)$. Uranium was extracted from this open mine from 1982 to 1995, to supply Angra I reactor power plant and other projects in Brazil. The whole area comprises the mine pit, which has $1.2 \mathrm{~km}$ of diameter and $176 \mathrm{~m}$ depth. Now it is a pond with the acid mine drainages, besides extensive areas intended for disposing of waste rock piles, several acids mine drainage ponds, settling ponds, and the inactivated uranium production unit. The pond waters comprise a complex mixture of metals with low $\mathrm{pH}$ and some radioactivity (Table 1) (Fernandes et al., 1998; Wiikman, 1998; Cipriani, 2002). The overall management system of these effluents is illustrated in Figure 1. Acid drainages are pumped into the mine pit, and then to the chemical plant for the physical-chemical treatment with $\mathrm{CaCO}_{3}$ and $\mathrm{CaO}$. In the past, the slurry from the drainage treatment was deposited in the tailing dam. However, because its full capacity, the precipitate from the chemical treatment is now being deposited in the mine open pit. The effluent from the tailing dam is treated with $\mathrm{BaCl}_{2}$, to remove radium isotopes from the solution, and the precipitated solids settle in two ponds (Fig. 1). The overflow of these two ponds is discharged into the Verde River (Fernandes et al., 2008).

We collected water samples from the five following sites in three sampling events, on September and November 2008 and on March 2009:

P1 - Pond containing untreated acid drainage from waste rock pile 4;

P2 - Mine pit that receives untreated effluent from P1 and slurry from physical-chemical treatment;

P3 - Settling pond that receives treated effluent from P1 and $\mathrm{P} 2$, treated with $\mathrm{CaCO}_{3}$ and $\mathrm{CaO}$;

P4 - Settling pond that receives effluents treated with $\mathrm{BaCl}_{2}$, and are then discharged to a local water body (Verde River);

P5 - Reservoir that receives water from a local river and treated effluents from P3, which is then discharged to a local water body (Antas Creek).

Table 1 - Average, minimum and maximum concentrations of pollutants in the P1 site, as determined by Fernandes et al. (1998) .

\begin{tabular}{cccc}
\hline Element & Average & Minimum & Maximum \\
\hline${ }^{226} \mathrm{Ra}\left(\mathrm{Bq} \mathrm{L} \mathrm{L}^{-1}\right)$ & 0.29 & 0.14 & 0.58 \\
${ }^{238} \mathrm{U}\left(\mathrm{Bq} \mathrm{L}^{-1}\right)$ & 175 & 71 & 315 \\
$\mathrm{Al}\left(\mathrm{mg} \mathrm{L}^{-1}\right)$ & 96 & 61 & 161 \\
$\mathrm{~F}\left(\mathrm{mg} \mathrm{L}^{-1}\right)$ & 99 & 5.1 & 167 \\
$\mathrm{Mn}\left(\mathrm{mg} \mathrm{L}^{-1}\right)$ & 75 & 6.6 & 105 \\
\hline \multicolumn{4}{c}{ Adapted from Fernandes et al. (1998). }
\end{tabular}




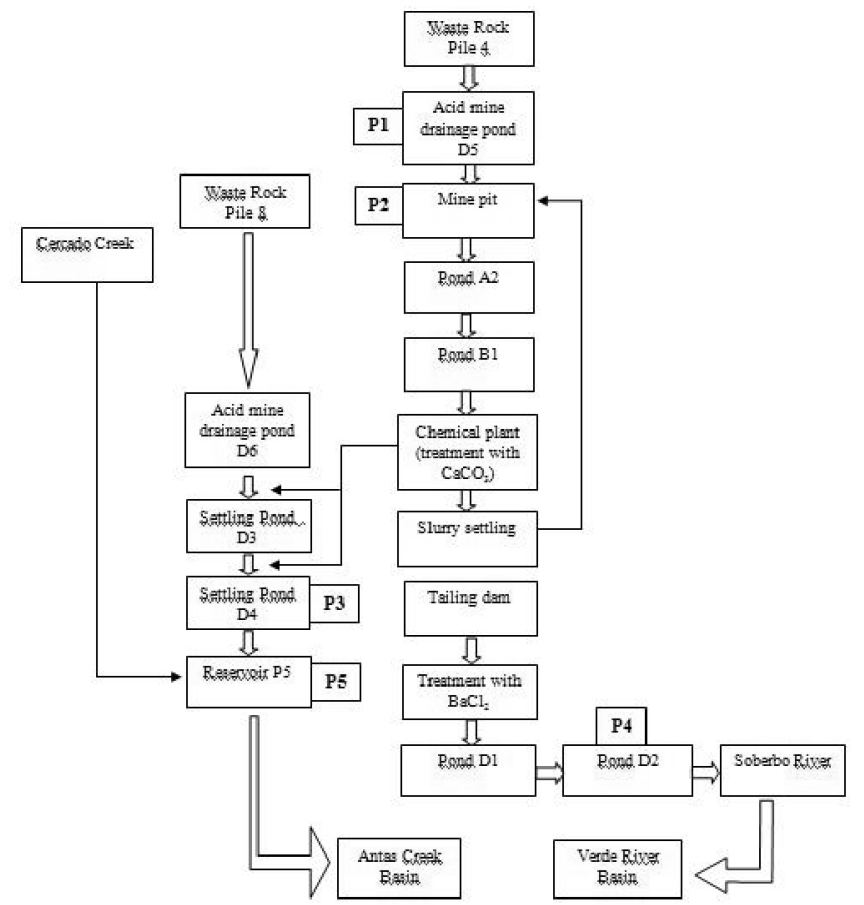

Figure 1. Flowchart of effluent and acid mine drainage treatments inside the inactivated uranium mine in Poços de Caldas, Brazil. Sampling sites are depicted as P1-P5, which are described in detail in the Materials and Methods Section. (Adapted from Cipriani, 2002).

\section{Samples}

We collected the water samples in nontoxic plastic containers, and stored them at $4^{\circ} \mathrm{C}$ in the dark until the moment of testing. Due to very low $\mathrm{pH}$ of samples P1 and P2 observed in the two first sampling events, $\mathrm{pH}$ values of samples from the third sampling event were corrected to $7.0 \pm 0.5$ with addition of $\mathrm{NaOH} 1 \mathrm{~N}$, to reach a biologically acceptable range.

\section{Physical-chemical parameters}

We determined physical-chemical parameters at the moment of sampling using a multiprobe equipment (model YSI-556). For each sample, values of $\mathrm{pH}$, conductivity, dissolved oxygen and temperature were registered.

\section{Bioassays}

We used bioassays to assess the efficiency of physicalchemical treatments in relation to toxicity, which were used in each sampling event as shown in Table 2.

\section{Vibrio fischeri}

We performed $V$. fischeri bioassay with water samples, as detailed in Knie and Lopes (2004), with some modifications. We performed laboratory tests using the field equipment (Biofix ${ }^{\circledR}$ Lumi-10-Macherey-Nagel). For each replicate 300 $\mu \mathrm{L}$ of suspended bacteria was used, in a 1:2 diluting series. Due to dilution caused by the addition of bacteria, the maximum
Table 2 - Bioassays performed in the studied area in three different sampling events.

\begin{tabular}{|c|c|c|c|c|}
\hline & & \multicolumn{3}{|c|}{ Sampling events } \\
\hline \multicolumn{2}{|c|}{ Sample site } & $\# 1$ & $\# 2$ & $\# \mathbf{3}$ \\
\hline \multirow[b]{2}{*}{ Untreated } & $\mathrm{P} 1 *$ & & & Acute tests: \\
\hline & $\mathrm{P} 2 *$ & Acute test: & Acute test: & $\begin{array}{c}\text { Daphnia } \\
\text { similis }\end{array}$ \\
\hline \multirow{3}{*}{ Treated } & P3 & $\begin{array}{l}\text { Daphnia } \\
\text { similis }\end{array}$ & $\begin{array}{l}\text { Daphnia } \\
\text { similis }\end{array}$ & $\begin{array}{l}\text { Vibrio } \\
\text { fischeri }\end{array}$ \\
\hline & P4 & & & Chronic test: \\
\hline & P5 & & & $\begin{array}{c}\text { Ceriodaphnia } \\
\text { dubia }\end{array}$ \\
\hline
\end{tabular}

*pH adjusted in the third sampling event.

concentration tested was $63 \%$, followed by $31.5 \%, 15.75 \%$ and $7.88 \%$. Percentages of light inhibition were used to calculate the $\mathrm{IC}_{50}(15 \mathrm{~min})$ of each sample, by the Trimmed-Spearman Karber method (Hamilton et al., 1977). Sensitivity tests were performed with zinc sulfate as the reference toxicant.

\section{Daphnia similis}

We kept $D$. similis stock cultures and acute toxicity test according to procedure NBR 12713 (ABNT, 2004). Final concentrations (Table 3 ) were determined after a preliminary test. After $48 \mathrm{~h}$, the immobilization of test organisms was registered and the $\mathrm{EC}_{50}(48 \mathrm{~h})$ estimated by the Trimmed-Spearman Karber method (Hamilton et al., 1977). Test data were considered acceptable if mortality in controls did not exceed $10 \%$.

In the third sampling event, we adjusted $\mathrm{pH}$ values of the samples with the lowest pH (P1 and P2) (Table 4), to $7.0 \pm 0.5$ and tested them before and after adjustment at $0.1,1,10$ and $100 \%$ concentrations.

\section{Ceriodaphnia dubia}

We kept the stock cultures and did the chronic toxicity test procedures of $C$. dubia according to NBR 13373 (ABNT, 2005). The endpoint was the total neonate production per female. The final concentrations tested for each sample are detailed in Table 3 . These data were used to estimate $\mathrm{IC}_{25}$, using

Table 3 - Concentrations of the tested samples for acute (D. similis) and chronic (C. dubia) toxicity.

\begin{tabular}{ccc}
\hline \multirow{2}{*}{ Samples } & \multicolumn{2}{c}{ Tested sample concentrations (\%) } \\
\cline { 2 - 3 } & D. similis & C. dubia \\
\hline P1 & $0.01 ; 0.1 ; 0.5 ; 1.0 ; 5.0 ; 10.0$ & $0.001 ; 0.01 ; 0.1 ; 1.0$ \\
P2 & $0.1 ; 0.5 ; 1.0 ; 5.0 ; 10.0$ & $0.001 ; 0.01 ; 0.1 ; 1.0$ \\
P3 & $1 ; 5 ; 10 ; 25 ; 50 ; 75 ; 100$ & $0.1 ; 1 ; 5 ; 10 ; 100^{\mathrm{a}}$ \\
P4 & $10 ; 25 ; 50 ; 100$ & $1 ; 5 ; 10 ; 50 ; 100^{\mathrm{a}}$ \\
P5 & $10 ; 25 ; 50 ; 100$ & $10 ; 50 ; 75 ; 100$ \\
\hline
\end{tabular}

a $100 \%$ samples were added in the third sampling event. 
the ICp software v. 2.0. Values of NOEC (No Observed Effect Concentration), LOEC (Lowest Observed Effect Concentration) and Chronic Value (CV, geometric mean of NOEC and LOEC) were determined for each sample with ANOVA $(p<0.05)$ and Tukey pos test. Test data were considered acceptable if mortality in the controls did not exceed $20 \%$ and neonate production per female in the controls was $\geq 15$.

\section{RESULTS AND DISCUSSION}

\section{Physical-chemical parameters}

Values of physical-chemical parameters are depicted in Table 4. Initially, we thought $\mathrm{pH}$ values could cause the observed toxicity, but two factors suggested otherwise: high dilution of tested samples naturally elevated $\mathrm{pH}$ values to a biologically acceptable range: all tested dilutions had $\mathrm{pH}$ values between 6,36 and 7,79; in the third sampling event $\mathrm{pH}$ values of $\mathrm{P} 1$ and $\mathrm{P} 2$ samples were adjusted to $7.0 \pm 0.5$. In both cases, toxicity was not completely removed from samples (see further sections). As expected, water conductivity was higher in untreated effluents (P1 and P2) than in the treated ones (P3$\mathrm{P} 5)$, indicating metal and other ion removal.

\section{Bioassays}

\section{Vibrio fischeri}

No reduction in light emission was observed for any tested sample. If metals are the cause of the toxicity observed

Table 4 - Physical-chemical parameters of tested samples.

\begin{tabular}{|c|c|c|c|c|c|}
\hline $\begin{array}{l}\text { Sampling } \\
\text { sites }\end{array}$ & Samplings & $\begin{array}{c}\text { Temperature } \\
\left({ }^{\circ} \mathrm{C}\right)\end{array}$ & $\begin{array}{c}\text { Dissolved } \\
\text { oxygen } \\
\left(\mathrm{mg} \mathrm{L}^{-1}\right) \\
\end{array}$ & $\mathrm{pH}$ & $\begin{array}{l}\text { Conductivity } \\
\left(\mu \mathrm{S} \mathrm{cm}^{-1}\right)\end{array}$ \\
\hline \multirow{3}{*}{$\mathrm{P} 1$} & $\# 1$ & 23.3 & 3.60 & 3.03 & 1271 \\
\hline & $\# 2$ & 19.9 & 4.04 & 3.51 & 1631 \\
\hline & $\# 3$ & 22.8 & 5.28 & 2.79 & 1550 \\
\hline \multirow{3}{*}{$\mathrm{P} 2$} & $\# 1$ & 23.8 & 3.42 & 3.82 & 1681 \\
\hline & $\# 2$ & 20.8 & 4.27 & 4.12 & 2549 \\
\hline & $\# 3$ & 28.5 & 5.12 & 2.38 & 1864 \\
\hline \multirow{3}{*}{ P3 } & $\# 1$ & 24.7 & 4.32 & 8.44 & 920 \\
\hline & $\# 2$ & 21.1 & 4.01 & 7.13 & 1100 \\
\hline & $\# 3$ & 25.0 & 6.30 & 6.41 & 700 \\
\hline \multirow{3}{*}{ P4 } & $\# 1$ & 24.2 & 4.40 & 7.35 & 494 \\
\hline & $\# 2$ & 20.9 & 4.71 & 6.58 & 987 \\
\hline & $\# 3$ & 26.5 & 5.50 & 6.79 & 548 \\
\hline \multirow{3}{*}{ P5 } & $\# 1$ & 23.3 & 5.46 & 7.56 & 629 \\
\hline & $\# 2$ & 20.9 & 4.16 & 6.60 & 235 \\
\hline & $\# 3$ & 26.1 & 6.00 & 5.64 & 134 \\
\hline
\end{tabular}

for $D$. similis (see section 3.2.2), it would be expected that $V$. fischeri would provide negative results, because it is known that this bacteria is less sensitive to metals than Daphnia (Teodorovic et al., 2009). Other possible explanation for the negative results would be the fact that the highest concentration tested was $63 \%$ in the $V$. fischeri assay in contrast to the $100 \%$ in $D$. similis test. Initially, we chose $V$. fischeri bioassay because it is easy-to-handle, time- and cost-effective, but it was not useful to us to determine the efficiency of the physical-chemical treatment in relation to toxicity. Antunes et al. (2008) used $V$. fischeri bioassay to assess toxicity of soil elutriates from an abandoned uranium mine, and also did not observe toxicity. Lopes et al. (1999) also unsuccessfully applied $V$. fischeri assay to test acid mine drainages from an inactivated cupric pyrite mine. They addressed several issues for this unsuccessful use of $V$. fischeri assay: (a) the interaction between metals and the test osmotic regulator might influence bacteria response; and/or (b) the influence of $\mathrm{pH}$ on metal speciation. Our results agree with their conclusion that $V$. fischeri bioassay is not adequate to assess the toxicity of acid mine drainages because several interactions can interfere with toxicity results.

\section{Daphnia similis}

Results of $D$. similis bioassays showed acute toxicity only in P1 and P2 samples, i.e., to untreated effluent samples (Table 5). Data published elsewhere (Fernandes et al., 2008) showed significant concentrations of metals at P1 sampling site (Table 1 ), suggesting that these metals can be the cause of toxicity. In the third sampling event, after $\mathrm{pH}$ adjustment in two samples, $\mathrm{P} 1 \mathrm{EC}_{50}$ values decreased to up to $17 \%$ and $\mathrm{P} 2 \mathrm{EC}_{50}$ up to $38 \%$ (Table 5). Even though, these results can also be considered toxic to $D$. similis. Physical-chemical treatment performed in the uranium mine treatment plant comprises of an elevation of $\mathrm{pH}$, with the addition of $\mathrm{CaCO}_{3}$ and $\mathrm{CaO}$. The same procedure was made in the present study. The toxicity of sample P3 also had a significant $\mathrm{EC}_{50}$ of $38 \%$ in the third sampling event. Samples P4 and P5 did not show acute effect to D. similis in any of the sampling events. These results suggest that removal of toxic substances was performed by physical-chemical treatment.

Table $5-\mathrm{EC}_{50}(\%)$ values for the acute toxicity test with $D$. similis.

\begin{tabular}{cccc}
\hline \multirow{2}{*}{ Samples } & \multicolumn{3}{c}{$\mathbf{E C}_{\mathbf{5 0}} \mathbf{( 4 8}$ h) - Sampling events } \\
\cline { 2 - 4 } & $\# \mathbf{1}$ & $\mathbf{\# ~ 2}$ & $\mathbf{\# ~ 3}$ \\
\hline P1 & 0.4 & $<0.01$ & 1.99 \\
P1 - adjusted pH & a & a & 17.11 \\
P2 & 1.05 & 0.9 & 2.41 \\
P2 - adjusted pH & a & a & 37.75 \\
P3 & NT & NT & 38.26 \\
P4 & NT & NT & NT \\
P5 & NT & NT & NT \\
\hline
\end{tabular}

a: Not performed. NT: Not toxic. 
Lopes et al. (1999) successfully used an acute toxicity test with $C$. dubia in samples of acid mine drainages from an inactivated cupric pyrite mine. The authors also corrected $\mathrm{pH}$ values prior to testing, intending to separate toxicity due to low $\mathrm{pH}$ from that due to metals. Lin et al. (2007) reported acute toxicity to Daphnia carinata in river water up to $25 \mathrm{~km}$ downstream of an iron and cupric ore mines, after a major flood event. They addressed both the impact of an acid mine drainage discharging into the environment, and possible flood impacts on surrounding environments of an inactivated mine.

Antunes et al. (2007a and 2007b) reported acute toxicity $\left(\mathrm{EC}_{50}(48 \mathrm{~h})\right)$ for Daphnia longispina from 20.5 to $28.4 \%$ and for Daphnia magna from 35.8 to $50.4 \%$ in ponds of an abandoned uranium mine in Portugal. They also found no acute toxicity in a pond that had its effluent treated with $\mathrm{BaCl}_{2}$, similarly to results found at $\mathrm{P} 4$ site, which also has treated effluent with the same reagent.

\section{Ceriodaphnia dubia}

Chronic toxicity results of C. dubia for the third sampling event are detailed in Table 6. All tested samples caused chronic toxicity to C. dubia, with NOEC ranging from 0.01 to $5 \%$, and LOEC from 0.1 to $10 \%$. This chronic bioassay also showed higher toxicity in untreated effluents, as expected, but also showed that physical-chemical treatment was not able to completely remove chronic toxicity to this organism. Even the lowest tested concentration of sample P5 (10\%) caused chronic toxicity which did not allowed NOEC estimation. $\mathrm{IC}_{25}(7 \mathrm{~d})$ values varied from $0.04 \%$ to $7.05 \%$. Chronic Values varied from 0.03 to $7.07 \%$. Values of NOEC and CV from Sample P5 could not be estimated, because even the lowest tested concentration was toxic to C. dubia. $\mathrm{IC}_{50}$ were also estimated, but only $\mathrm{IC}_{25}$ values were reported, for we considered them more protective of aquatic life.

Antunes et al. (2007b) reported chronic toxicity to $D$. magna to different endpoints (total number of offspring, number of broods, age at first reproduction, somatic growth rate, and rate of population increase) when they assessed an untreated effluent pond of a Portuguese uranium mine. However, they found both deleterious and stimulatory effects with $D$. longispina and $D$. magna. The same authors also reported that receiving water bodies with less water flow might not be able to sufficiently dilute effluents to avoid chronic toxicity to indigenous aquatic organisms. In our study we

Table 6 - Chronic toxicity values (\%) for $C$. dubia.

\begin{tabular}{ccccc}
\hline Samples & $\mathbf{I C}_{\mathbf{2 5}}$ (7 days) & NOEC & LOEC & $\mathbf{C V}$ \\
\hline P1 & 0.04 & 0.01 & 0.1 & 0.03 \\
P2 & 0.05 & 0.01 & 0.1 & 0.03 \\
P3 & 1.04 & 1.0 & 5.0 & 2.23 \\
P4 & 7.05 & 5.0 & 10.0 & 7.07 \\
P5 & 4.11 & $<10.0$ & 10.0 & $<10.0$ \\
\hline
\end{tabular}

observed chronic toxicity to $C$. dubia even after the treatment but unfortunately we did not have access to water flow rates of the receiving water bodies influenced by the discharge of the effluents from the inactivated uranium mine plant. Thus, we could not estimate the impact that these effluents might have on aquatic life.

Based on metal determinations from the untreated acid drainage basins published by Fernandes et al. (2008), it is possible that uranium concentrations had a significant contribution to the toxicity of P1 and P2 samples, although the metal determinations were not performed in the samples that toxicity was measured. The ${ }^{238} \mathrm{U}$ concentrations of these sites were 16.6 and $24.8 \mathrm{mg} \mathrm{L}^{-1}$, respectively. However, more studies would be required to better determine which compounds are causing the toxicity in the effluents from the studied mine. Antunes et al. (2007b) reported that mine effluents are complex mixtures, and toxicity cannot be entirely attributed to a single toxicant, because even non toxic substances might have a synergistic effect and cause toxicity. Toxicity Identification and Evaluation (TIE) could be a proper tool to assess the studied effluent.

\section{CONCLUSIONS}

Adjustment of $\mathrm{pH}$ was not enough to completely remove acute toxicity to $D$. simils, demonstrating that other substances are present at toxic levels in the uranium mine effluent. $V$. fischeri, although an easy-to-handle, time- and cost-effective bioassay, was not sensitive to detect toxicity of the mine effluent samples. The physical-chemical treatment applied by the facility was not efficient to remove the toxicants at nontoxic levels to C. dubia, suggesting that treatment improvement would still be necessary. Surface water Brazilian regulations CONAMA 357/2005 and CONAMA 430/2011 requires that effluents must not have the potential to impact the aquatic life of the water bodies classified as 1,2 or 3. To determine the possible impact caused by the discharge of these effluents both effluent and river flow need be considered.

\section{ACKNOWLEDGEMENTS}

The authors wish to thank prof. Dr. Abilio Lopes who started this project (In memorian); Ana Sofia Gaspar and Sandra Gonçalves for initial data; the mine facility that allowed effluent sampling and provided valuable information about the treatment, Dr. David Demarini for revising our manuscript; UBIOTECH Company for providing the luminometer and bacteria for testing. Mariana C. Artal thanks CNPq/PBIC for the fellowship (Proc. 109705/2008-4).

\section{REFERENCES}

ANTUNES, S.C., FIGUEIREDO, D.R., MARQUES, S.M., CASTRO, B.B., PEREIRA, R. \& GONÇALVES, F., 2007a.. Evaluation of water column and sediment toxicity from an abandoned uranium mine using a battery of bioassays. Sci. Total Environ. 374, 252- 
259. http://dx.doi.org/10.1016/j.scitotenv.2006.11.025

ANTUNES, S.C., PEREIRA, R. \& GONÇALVES, F., $2007 \mathrm{~b}$. Acute and chronic toxicity of effluent water from an abandoned uranium mine. Arch. Environ. Contam. Toxicol. 53, 207-213. http://dx.doi.org/10.1007/s00244-006-0011-9

ANTUNES, S.C., CASTRO, B.B., PEREIRA, R. \& GONÇALVES, F., 2008. Contribution for tier 1 of the ecological risk assessment of Cunha Baixa uranium mine (Central Portugal): II. Soil ecotoxicological screening. Sci. Total Environ. 390, 387-395. http://dx.doi.org/10.1016/j.scitotenv.2007.07.053

Associação Brasileira de Normas Técnicas (ABNT), 2004. Ecotoxicologia aquática - Toxicidade aguda - Método de ensaio com Daphnia spp (Cladocera, Crustacea), NBR 12.713.

Associação Brasileira de Normas Técnicas (ABNT), 2005. Ecotoxicologia aquática - Toxicidade crônica - Método de ensaio com Ceriodaphnia spp (Cladocera, Crustacea), NBR 13.373.

CIPRIANI, M., 2002. Mitigação dos Impactos Sociais e ambientais decorrentes do Fechamento definitivo de minas de urânio. Doutorado em Geociências - Administração e Política de Recursos Minerais - Instituto de Geociências, Universidade Estadual de Campinas, Campinas, 334 p.

Conselho Nacional do Meio Ambiente (CONAMA), 2005. Resolução 357, de 17 de março de 2005, Brasília, Distrito Federal, available in www.mma.gov.br.

Conselho Nacional do Meio Ambiente (CONAMA), 2011. Resolução 430, de 13 de maio de 2011, Brasília, Distrito Federal, available in www.mma.gov.br.

FERNANDES, H.M., FRANKLIN, M.R. \& GOMIEIRO, L.A., 2008. Critical analysis of the waste management performance of two uranium production units in Brazil - part I: Poços de Caldas production centre. J. Environ. Manage. 87, 59-72. http://dx.doi. org/10.1016/j.jenvman.2007.01.045

FERNANDES, H.M., FRANKLIN, M.R. \& VEIGA, L.H., 1998. Acid rock drainage and radiological environmental impacts. A study case of the Uranium mining and miling facilities at Poços de Caldas. Waste Manage. 18, 169-181. http://dx.doi.org/10.1016/ S0956-053X(98)00019-1

GALAN, E., GOMEZ-ARIZA, J.L., GONZALEZ, I., FERNANDEZCALIANI, J.C., MORALES, E. \& GIRALDEZ, I., 2003. Heavy metal partitioning in river sediments severely polluted by acid mine drainage in the Iberian Pyrite Belt. Appl. Geoch.18, 409421. http://dx.doi.org/10.1016/S0883-2927(02)00092-6
HAMILTON, M.A., RUSSO, R.C. \& THURSTON, R.V., 1977. Trimmed Spearman-Karber method for estimating median lethal concentration in toxicity bioassays. Environ. Sci. Technol. 11, 714-719. Correction: 1978, 12: 417.

KNIE, J.L.W. \& LOPES, E.W.B., 2004. Testes ecotoxicológicos Métodos, técnicas e aplicações. Florianópolis, FATMA/GTZ, $289 \mathrm{p}$.

LIN, C., WU, Y., LU, W., CHEN, A. \& LIU, Y., 2007. Water chemistry and ecotoxicity of an acid mine drainage-affected stream in subtropical China during a major flood event. J. Hazard. Mater. 142, 199-207. http://dx.doi.org/10.1016/j. jhazmat.2006.08.006

LOPES, I., GONÇALVES, F., SOARES, A.M.V.M. \& RIBEIRO, R., 1999. Discriminating the ecotoxicity due to metals and to low $\mathrm{pH}$ in acid mine drainage. Ecotoxicol. Environ. Safe. 44, 207214. http://dx.doi.org/10.1006/eesa.1999.1825

NEVES, O., ABREU, M.M. \& VICENTE, E.M., 2008. Transferência do urânio no sistema água-solo-planta (Lactuca sativa, L.) na área mineira da Cunha Baixa. Geociences. 5(3): 1-8.

RUBIO, J. \& SILVA, R., 2010. Tratamento de drenagem ácida de minas de carvão: Tendências Tecnológicas. Portal Tratamento de Água. Accessed on: Oct-10-2010. http://www.tratamentodeagua. com.br/r10/Lib/Image/doc_1514599320_Drenagem\%20 $\%$ C3\%81 cida $\% 20 \mathrm{de} \% 20$ Minas\%20no\%20Brasil.pdf.

SHEPPARD, S.C., SHEPPARD, M.I., GALLERAND, M.O. \& SANIPELLI, B., 2005. Derivation of ecotoxicity thresholds for uranium. J. Environ. Radioact. 79, 55-83. http://dx.doi. org/10.1016/j.jenvrad.2004.05.015

TEODOROVIC, I., PLANOJEVIC, I., KNEZEVIC, P., RADAK, S. \& NEMET, I., 2009. Sensitivity of bacterial vs. acute Daphnia magna toxicity tests to metals. Cent. Eur. J. Biol. 4, 482-492. http://dx.doi.org/10.2478/s11535-009-0048-7

VERA, T.F., BLANCO, R.P. \& LOZANO, J.C., 2002. Distribution and mobilization of $\mathrm{U}, \mathrm{Th}$, and ${ }^{226} \mathrm{Ra}$ in the plant-soil compartments of a mineralized uranium area in south-west Spain. J. Environ. Radioact. 59, 41-60.

WIIKMANN, L.O., 1998. Caracterização química e radiológica dos estéreis provenientes da

mineração de urânio do Planalto de Poços de Caldas. - Mestrado em Ciências- Escola Superior de Luiz de Queiróz, Universidade de São Paulo, Piracicaba, São Paulo, 98p. 